\title{
THE FINANCING RESTRUCTURING LEGAL ANALYSIS FOR DEBTORS AFFECTED BY COVID-19 IN SHARIA MULTIFINANCE INSTITUTIONS
}

\author{
Andi Aina Ilmih \\ Sultan Agung Islamic University \\ andiaina@unissula.ac.id \\ Kami Hartono \\ Sultan Agung Islamic University \\ kami.h@unissula.ac.id \\ Ida Musofiana \\ Sultan Agung Islamic University \\ ida.musofiana@unissula.ac.id
}

\begin{abstract}
This study focuses on problematic financing by debtors affected by Covid-19 at Islamic multi-finance institutions in Semarang City, with the aim of finding the reality of the form of problematic financing experienced by debtors during the Covid-19 Pandemic. This study uses an empirical juridical approach, data analysis using descriptive-analysis methods. Based on the research that has been done, the regulation of the Financing Restructuring Law is guided by POJK Number 11/POJK.03/2020 concerning National Economic Stimulus as a Countercyclical Policy on the Impact of Coronavirus Disease 2019 which regulates asset determination, financing restructuring and provision of new funds. The impact arising from the existence of a financing restructuring policy for debtors affected by Covid-19 can be viewed from the following aspects: (1)Juridical Aspect, meaning that there are no sanctions for the financing institution as a creditor if it does not follow or apply, only based on the willingness of the creditor; (2) Economic Aspect, can help debtors to recover and stabilize the economy so that they can fulfill promises (achievements) to creditors; and for creditors the impact on financial activities or transactions that occurred during the Covid-19 pandemic can still be stable; (3)Psychological Aspects, meaning that one side fosters a strong mentality and confidence for creditors/financing customers to fulfill their obligations, and on the other hand, the existence of the presence of financial institutions is maintained in the future.
\end{abstract}

Keywords: Financing Restructuring; Multifinance Institutions; Sharia Financing.

\section{A. INTRODUCTION}

Indonesia is one of the countries with the largest Muslim majority in the world, but also a country with high needs. The existence of a high need demands the fulfillment of needs quickly and precisely based on technology. With the rapid development of technology, it has brought progress in almost 
all aspects of human life. ${ }^{1}$ One of the rapid developments is the use of financing products to meet increasingly diverse human needs.

The presence of financing products with a sharia system that can be used as the right solution, because in addition to meeting the criteria and in accordance with Islamic law, this system or sharia principles is also known as a fulfillment service that does not violate religious rules, so that people prefer these services to avoid this. -things that should not be done as a Muslim.

There is a rapid development in the field of financing, namely the use of digital technology-based financing products, which have made it easy at the beginning with the development of online financing products that allow humans to access quickly without being hindered by space and time boundaries.

Cita Yustisia Serfiani ${ }^{2}$, In addition to the availability of online-based tools, it is also related to the birth of electronic contracts. Electronic contracts (E-contracts) are made through an electronic system. "Electronic system" is a series of electronic devices and procedures that serve to prepare, collect, process, analyze, store, display, announce, transmit and/or disseminate electronic information.

The advancement of technology development is apparently not in line with the conditions faced by almost all countries in the world with the Corona Virus Disease (Covid-19) outbreak. The spread of Covid-19 was able to paralyze the economies of several countries and have an impact in almost all aspects of life. Especially for those who depend on their work from direct transactions (face to face) in society. This also affects the majority of people who use financing to meet their needs.

Islamic or Islamic financing (bank) activities are a sub-sector of the Islamic economy, which is defined as a devout economy, with a starting point from Allah and with the ultimate goal of Allah, and using means that cannot separated from Islamic law. ${ }^{3}$

One of the largest financial service providers in Indonesia, namely the Home Credit Indonesia company (PT Home Credit). With the increasing number of contracts (financing) that occurred at Home Credit Indonesia, ethically, morally, it also has a big responsibility to the Indonesian people as consumers of the Home Credit online financing institution when a dispute occurs at a later date. ${ }^{4}$ During the Covid-19 pandemic, many debtors/customers at multi-finance institutions found it difficult to meet the obligation to pay credit/installments on time (normal conditions), including this financing institution. Apart from Home Credit, there is also Amitra Syariah Financing, which is a Sharia Financing managed by FIFGROUP, which is a

1 Agus Rahardjo, CyberCrime: Understanding and Efforts to Prevent Technology Crime, PT. Citra Aditya, Bandung, 2002, page.1

2 Cita Yustisia Serfiani et al, Smart Book Online Business and Electronic Transactions, Gramedia Pustaka Utama, Jakarta, 2013, page. 99

3 Qardhawi, Yusuf, Norma dan Etika Ekonomi Islam, Gema Insani Press, Jakarta, 1997, page.31.

4 Andi Aina Ilmih, A.Zulkarnain, Ideal Electronic Contract Model As A Form Of E-Commerce Disputes Settlement, Jurnal Pembaharuan Hukum, Volume VI No.1 January-April 2019, page.81. 
subsidiary of ASTRA which specializes in financing Umrah \& Hajj religious trips. 5

Various efforts have been made by the Government to anticipate a greater impact due to Covid-19. One of them is by maximizing the use of digital technology. Including in the case of financial transactions, it is hoped that financing products will provide a very broad space to transact in a more sharia manner. The large number of online financing product offers (considered a modern system) is expected to be able to fully apply sharia values, especially in Islamic financial institutions or financing institutions (multi) in Indonesia, both in normal conditions (safe transactions) or in a condition that is prone to current problems faced by debtors of financing or multi-finance institutions, both conventional and sharia.

YLKI data recorded that there were 10 (ten) major consumer complaints based on commodities, namely banking with 106 cases, online loans with 96 cases, housing for 81 cases and online shopping in 34 cases. Then for the problem of leasing complaints of 32 cases, transportation 26 cases, electricity 24 cases, telecommunications 23 cases, insurance 21 cases and public services 15 cases. $^{6}$

The Indonesian Consumers Foundation (YLKI) said there were at least 39 reports from the public regarding the credit relief program launched by the government for customers affected by COVID-19. Complaints about credit relief programs or related to financial services reached $11 \%$ of the total complaints about the corona pandemic. Some problems have been complained by the public, for example when the customer is applying for credit relief, the debt collector continues to collect installments. ${ }^{7}$

The Financial Services Authority (OJK) provides leniency/relaxation for micro and small business credit for a value below IDR 10 billion, both credit/financing provided by banks and the non-bank financial industry to bank debtors will be given a delay of up to 1 (one) year and decreased interest. This is stated in the provisions governing in general the implementation of credit/financing restructuring as a result of the impact of the spread of the COVID-19 virus.

Based on the description above, the author will analyze the extent to which the legal arrangements for restructuring financing for debtors of Islamic multi-finance institutions in Indonesia and analyze the impact of the existence of financing restructuring legal arrangements for debtors affected by Covid-19 in Islamic multi-finance institutions in solving problematic financing problems, especially in the City area, Semarang.

5 Mukhlis Lubis, Inovasi Sistemik Pembiayaan Perjalanan Umrah Melalui Amitra Syariah Financing (Studi Kasus PT. Wakafa Zain Abul Husna), Jurnal Islamic Circle, Vol.1. No.1, June 2020, Page.83 6 https://money.kompas.com/read/2020/01/14/165643726/ylki-jumlah-pengaduan-jasa-keuanganmeningkat. "YLKI: Jumlah Pengaduan Jasa Keuangan Meningkat", accessed on 14 February 2020, at 19.00 Wib.

7 https://finansial.bisnis.com/read/20200408/89/1224406/ylki-terima-39-pengaduan-keringanan-kr edit-dampak-covid-19, accessed on 10 April 2020, at 12.30 Wib. 


\section{B. RESEARCH METHODS}

This research uses an empirical juridical research method, which means that in analyzing legal problems it is done by combining legal materials (which are secondary data) with primary data obtained in the field or at research locations related to the implementation of restructuring of financing for debtors affected by Covid-19. Accurate data/information collection with primary data as support/support and secondary data from literature studies. Primary data were obtained by means of observational surveys (through financing documents) and interviews ${ }^{8}$ to related parties, in this case the debtor affected by Covid-19 at the Sharia Financing Institution. Meanwhile, secondary data is obtained by conducting literature studies, either through reference books, seminar papers, legal regulations and research results related to the object of research. The data analysis used in this research is descriptive-qualitative by analyzing data/information obtained through descriptive research with library research which is then arranged systematically and described qualitatively.

\section{RESULT AND DISCUSSION}

\section{Legal Regulations for Financing Restructuring in Sharia Multi-Finance Institutions in Indonesia}

The development of the spread of coronavirus disease 2019 (COVID-19) has a direct or indirect impact on the performance and capacity of debtors including micro, small and medium business (MSME) debtors, so that it has the potential to disrupt the performance of banks, financing institutions and financial system stability which can affect growth the economy. Therefore, to promote the optimization of the intermediation function, maintain financial system stability and support economic growth, economic stimulus policies are required.

POJK Number 11/POJK.03/2020 concerning National Economic Stimulus as a Countercyclical Policy on the Impact of the Spread of Coronavirus Disease 2019. Countercyclical is a policy that maintains economic stability during a recession (Covid-19 Pandemic). This policy is carried out expansively in the form of fiscal and monetary easing, as well as is expected as a form of handling problematic financing problems faced by the community.

The POJK provisions were issued to stimulate the economy in the form of restructuring for debtors affected by Covid-19. The application of this policy applies to all banks and financial institutions, both with conventional and sharia systems. Looking further, in this POJK, the category of debtors affected by Covid-19 is not only banking debtors or financing institutions, but also including MSME debtors.

The POJK provisions were issued to stimulate the economy in the form of restructuring for debtors affected by Covid-19. The application of this policy applies to all banks and financial institutions, both with conventional and sharia systems. Looking further, in this POJK, the 
category of debtors affected by Covid-19 is not only banking debtors or financing institutions, but also including MSME debtors.

The POJK provisions were issued to stimulate the economy in the form of restructuring for debtors affected by Covid-19. The application of this policy applies to all banks and financial institutions, both with conventional and sharia systems. Looking further, in this POJK, the category of debtors affected by Covid-19 is not only banking debtors or financing institutions, but also including MSME debtors.

Three models are stimulated in the POJK, namely: First, the determination of asset quality, meaning that even though the condition is not smooth, the financing is still recorded as smooth. Second, the restructuring of financing because this will be a long discussion, because it is necessary to re-design and transact the contracts. Third, the provision of new funds. ${ }^{9}$

The main bases governing Sharia financing are: First, Surah Al-Baqarah (QS. 2: 275), which, among other things, states, "...however Allah has made trading lawful and forbidden usury". Second, Surah Al-Mā'idah (QS. 5: 2) which reads, "And cooperate in righteousness and piety, but do not cooperate in sin and aggression. And fear Allah; indeed, Allah is severe in penalty." In Islam, the fulfillment of obligations is mandatory and keeping promises must be done with sincerity, full of honesty and sincerity. ${ }^{10}$ (Nawawi, 2009: 51), because it is not only a positive legal provision, but also a commandment of God (QS. 5: 1).

Financing restructuring can only be carried out for financing with substandard, doubtful and non-performing quality. ${ }^{11}$ In practice, customers who are late in paying or affected by problematic financing will get a fine that has been determined at the beginning of the contract. ${ }^{12}$ The difference with other Sharia Financing Institutions, Amitra Syariah Financing does not impose sanctions on customers or congregants who are in arrears for installment payments.

In the event that the method of restructuring credit/financing is carried out as stipulated in the OJK regulations concerning asset quality assessment, among others by: 1) lowering interest rates; 2) extension of the period; 3) reduction of principal arrears; 4) reduction of interest

9 Pendapat Peri Farouk, Direktur Riset Hukum Indonesia, Dampak Yuridis POJK No. 11/2020 Terhadap Penanganan Pembiayaan Bermasalah pada Bank Syariah, downloaded from website:

https://kliklegal.com/dampak-yuridis-pojk-no-11-2020-terhadap-penanganan-pembiayaan-berm asalah-pada-bank-syariah/, on 16 June 2020 , at 13.00 WIB.

10 Nawawi, Razali HJ., Islamic Law on Commercial Transaction, CERT Publications, Kuala Lumpur, 2009, page.51.

11 Trisadini Prasastinah Usanti, Restrukturisasi Pembiayaan sebagai Salah Satu Upaya Penanganan Pembiayaan Bermasalah, Jurnal Perspektif, Volume XI No.3, Edition July 2016, page.273.

12 Roanna and Wage, Umrah Financing through Umrah Bailout Funds from the Fatwa Perspective of the National Sharia Council of the Indonesian Ulama, Journal of Islamic Studies " Alhambra", Volume 1, No. 1, February, 2020: 13-24 
arrears; 5) additional credit/financing facilities; and/or 6) credit/financing conversion to Temporary Equity Participation.

Related to problematic financing, what is meant is a situation where the customer is no longer able to pay part or all of its obligations to the bank/financing institution as agreed. The problem is, the POJK does not specify how the restructuring will be carried out, which will determine the form of the agreement or contract used by both parties between the debtor and creditor.

The term "problem" in this financing can be interpreted as a condition of default. This can be caused by the debtor himself because he is unwilling or unable to fulfill the promise he has made and it can also be caused by the creditor for making an agreement or contract that is burdensome to the debtor. If it is related to the current condition of the Covid-19 outbreak, it clearly indicates that it is not because of the unwillingness of the debtor to fulfill his promise, but because of an "overmacht" condition where it is beyond the ability and reach of the debtor as a human to reject this outbreak (human destiny).

Financing institutions can handle problematic financing efforts to maximize profits by relying on debtor financing, by minimizing cost of finance (losses). This is done on the basis of the consideration that the financing institution is trying to save and resolve the problems faced by both parties. The rescue effort is the first step taken by a financing institution by assessing the ability of the debtor to be in the "capable" category of fulfilling promises (achievements). As a last resort is a settlement effort that can be taken by a financing institution to terminate an agreement or contract with the customer/debtor.

Rescue efforts can be made through a financing restructuring program, as stipulated in POJK No. 11 of 2020, "... This is done with the aim of improving the customer's financing position and financial condition. The financing restructuring program can be carried out in 3 ways, namely through rescheduling, reconditioning, and restructuring, without prejudice to the aspects of sharia/Islamic law for Islamic financing institutions.

From the sharia aspect, financing restructuring is guided by Surah Al-Baqarah [2]; 279-280 which means "279. But if ye will do it not, then be apprised of war from Allah and His apostle. And if ye repent, then yours shall be your capital sums; ye shall neither wrong nor be wronged. 280. And if the debtor is in difficulty, give him respite till the time of ease; and your foregoing the entire debt from him is still better for you, if only you realise."

As for the grouping of financing restructuring in Islamic financing institutions into 4 models, namely: First, reduction or reduction in arrears for the results/ ujrah, as the National Sharia Council's ijma' to follow fatwas and OJK PBI regulations. Second, the extension of the period (rescheduling). Third, reduction of principal arrears. Fourth, additional facilities.

In general, in granting restructuring, Sharia Multifinance (Financing) Institutions, refer to POJK asset quality assessment. However, 
the implementation or restructuring scheme may vary and is largely determined by each policy. These various schemes are fully submitted to the Financing Institution and are highly dependent on the results of the identification of the debtor's financial performance or an assessment of the business prospects and capacity of paying debtors affected by COVID-19. The period of this restructuring varies greatly depending on the assessment of the bank/financing institution of the debtor with a maximum period of 1 (one) year.

The allowance of up to 1 (one) year refers to the restructuring period as stipulated in POJK Stimulus. The allowance for installments is intended more for small debtors, including the informal sector, micro-businesses, daily income workers who have credit payment obligations to run their productive businesses. For example, an informal worker who has a certain type of home ownership bill or a simple home program, a food stall entrepreneur who is forced to close because of the work from home policy.

Relaxation with postponement of principal payments up to 1 (one) year can be given to priority debtors. Within that one year period, the debtor can be given a postponement/scheduling of principal and/or interest for a certain period of time in accordance with the agreement or assessment of the bank/financing institution, for example 3,6, 9, or 12 months. The postponement period policy given is closely related to the impact of COVID-19 on debtors, including the period of business recovery and progress in handling/reducing the COVID-19 outbreak.

The existence of the POJK Stimulus emphasizes all Financial and Financing Institutions so that the provision of this restructuring policy is carried out responsibly and so that moral hazard does not occur, so that it is not used by irresponsible parties (freerider/aji mumpung-Javanese). This is related to debtors who were previously smooth but then clearly decreased their business performance as a result of COVID-19.

Financing Institutions through POJK Stimulus are asked to be more proactive in assisting their debtors by offering the right restructuring scheme, both in terms of timeframes, installments or interest relaxation. As an illustration of the form of moral hazard and irresponsible restructuring, among others, is the restructuring policy given to customers who before the outbreak of COVID-19 had problems but took advantage of this stimulus by giving blessings so that their debtor status would run smoothly. This disgraceful act must be avoided by Banks and Financing Institutions, including Sharia Financing Institutions.

\section{The impact caused by the existence of a financing restructuring policy for debtors affected by Covid-19 at Islamic multi-finance institutions in Semarang City}

Based on data from the Financial Services Authority (OJK), it shows that data per December 2014, the performance of Islamic finance institutions in Indonesia continues to experience positive developments. In 2010, the total assets of Islamic finance institutions consisting of Islamic 
commercial banks and Islamic business units reached IDR 97.52 trillion. In 2014 the total asset value increased to IDR 272.34 trillion, this means that during the 2010-2014 period it grew by an average of 33.5 percent. A positive trend also occurs in the ability to collect third party funds (DPK). In 2010, the total value of TPF collected by sharia financing institutions was IDR 76 trillion and in 2014 it increased to IDR 217.8 trillion. Finally, in 2018, Indonesia's total Islamic financial assets reached USD 86 billion, an increase of USD 4 billion from the previous year. The increase in total assets places Indonesia in the 7th position with the largest total Islamic financial assets in the world. ${ }^{13}$

The basic principle of Islamic economics and financing is to create the benefit or welfare of society, based on the main principles consisting of the Oneness of God, the concept of the Caliph of God on earth, justice and material and spiritual balance or worldly with the end. These principles can be fulfilled by following the basic provisions of financing, namely through trading activities and staying away from usury, as well as cooperation between people. ${ }^{14}$

The reality that is currently happening is that the increasing amount of funds collected by funds and Islamic financing institutions is not comparable with the efforts to protect the rights of consumers/customers. Many business actors/banks and financial institutions have a tendency to ignore consumer rights and take advantage of the weaknesses of their consumers without having to get legal sanctions. The lack of awareness and knowledge of the consumer community is not impossible to make land for business actors in transactions that do not have good faith in running a business, namely the principle of seeking maximum profit by making the most efficient use of existing resources. ${ }^{15}$

Siswanto Sutojo said, ${ }^{16}$ that non-performing loans can arise apart from causes from the creditor, some problematic financing arises because of something that happens to the debtor, including:

a. The decline in the business conditions of the company due to the decline in general economic conditions and/or the business fields in which they operate

b. There is mismanagement in the management of the company's business, or due to lack of experience in the field of business they handle.

13 Database OJK dalam Laporan Perkembangan Keuangan Syariah Indonesia, Accessed on Froday 15 october 2020, from website OJK:

https://www.ojk.go.id/id/kanal/syariah/data-dan-statistik/laporan-perkembangan-keuangan-sya riah-indonesia/Documents/LAPORAN\%20PERKEMBANGAN\%20KEUANGAN\%20SYARIAH\%20IN DONESIA\%202019.pdf

14 Hendy Herijanto, Prinsip, Ketentuan dan Karakteristik Pembiayaan (Bank) Syariah, Jurnal Islaminomic, Vol. V. No. 2, August 2016, page.53.

15 Husni Syawali dan Neni Sri Imaniyati, Hukum Perlindungan Konsumen, Mandar Maju, Bandung, 2000, page. 28.

16 Siswanto Sutojo, Analisa Kredit Bank Umum: Konsep dan Teknik, Jakarta: Pustaka Binaman Pressindo, 1995, page.25. 
c. There is mismanagement in the management of the company's business, or due to lack of experience in the field of business they handle.

d. Family problems, for example divorce, death, prolonged illness or waste of funds by one or more family members of the debtor.

e. The failure of the debtor in their other line of business or company.

f. Serious financial liquidity difficulties

g. The emergence of events outside the debtor's control, for example war and natural disasters, including the Covid-19 pandemic. 7. Bad character of the debtor (who had originally planned not to return the credit).

h. The failure of the debtor in their other line of business or company.

i. Serious financial liquidity difficulties.

j. The emergence of events outside the debtor's control, for example war and natural disasters, including the Covid-19 pandemic.

k. The debtor's bad character (who had originally planned not to return the credit).

To solve this financing-related problem, the provisions of POJK Number 11/POJK.03.2020 are used as a basis and guidelines for implementing a financing restructuring program for Islamic financing institutions during the Covid-19 pandemic. As in the POJK, there is a phrase "can apply policies". This term in fiqh is the same as Mubah Jaiz ${ }^{17}$, it means that it is permissible to do but not appreciated or there is no reward whatsoever.

The impacts arising from the issuance of POJK Number 11/ POJK.03.2020 are as follows:

a. Juridical Impact

The POJK provisions are limited to stimulation, there are no sanctions for banks or financial institutions as creditors if they do not follow or implement, and there is also no appreciation for creditors, only returning to the creditor's willingness to have good intentions for customers (debtors). In addition, debt collectors are asked to temporarily stop withdrawing vehicles, because this can help people who are directly affected.

With this POJK, it is hoped that the debtor can take advantage of the opportunity to get a restructuring by proposing restructuring to the financing/leasing institution to clarify the fulfillment of his obligations if it has been done. Applications can be submitted online (email/website specified by the bank/leasing) without having to come face to face. However, if the debtor has arrears to be more proactive in proposing restructuring. If the debtor still has obligations that must be fulfilled, the debtor must settle the arrears in question. Thus, the company does not need to send debt collectors to the debtor in question.

OJK hopes for the cooperation of the entire community to responsibly take advantage of the relaxation policy related to this payment. OJK is also currently investigating because there are several

17 Feri Farouk, Op.Cit. 
debt collectors who collect the leasing companies out of their knowledge. This also needs to be careful. If the debt collector is carried out by a financing company, it can be conveyed to the debt collector that it will take care of the restructuring and can be submitted to the leasing company.

b. Economic Impact

The economic impact on debtors, namely the existence of POJK stimulation greatly helps debtors in proposing restructuring in order to restore and stabilize their economy, by trying to reorganize the business or business they are running and on the other hand, they can still fulfill their promises (achievements) to creditors. Likewise for creditors, the existence of this restructuring policy has an impact on financial activities or transactions that occur during the Covid-19 pandemic which can still be stable so that they maintain the existence of the financing institution itself.

The establishment of the POJK was also accompanied by a request from the OJK for debt collectors not to withdraw debtors 'vehicles so that debtors can try to restructure and stabilize their economy, which will have an impact on the continuity of payments as fulfillment of debtors' obligations.

c. Psychological Impact

With the POJK as a financing restructuring policy, it fosters a strong mentality and confidence for debtors/financing customers to fulfill their obligations because they have been given sufficient opportunity and time to recover and stabilize their economy, while still trying as much as possible to fulfill their obligations according to the agreed timeframe. . On the other hand, the level of customer confidence in financial institutions is getting higher so that the existence of the presence of financial institutions is maintained in the future.

\section{CONCLUSION}

The Legal Regulation for Financing Restructuring in Sharia Multifinance Institutions, which is guided by POJK Number 11/POJK.03/2020 concerning National Economic Stimulus as a Countercyclical Policy on the Impact of the Coronavirus Disease 2019 Spread. This policy is used as a basis and guideline for implementing a financing restructuring program for financing institutions sharia during the Covid-19 pandemic. This policy regulates 3 things, namely: determination of assets, restructuring of financing and provision of new funds and the impact of the financing restructuring policy for debtors affected by Covid-19 at Islamic multi-finance institutions in Semarang City can be viewed from the following aspects: (1) Juridical aspect, meaning that there are no sanctions for the financing institution as a creditor if they do not follow or apply, only based on the willingness of the creditors; (2) Economic Aspect, meaning that one side helps debtors to restore and stabilize the economy and can still fulfill promises (achievements) to creditors. On the other hand, for creditors, the impact on financial activities or transactions that occurred 
during the Covid-19 pandemic could still be stable; (3) Psychological Aspects, meaning that one side fosters a strong mentality and confidence for creditors/financing customers to fulfill their obligations, and on the other hand, the existence of the presence of financial institutions is maintained in the future.

\section{Books :}

\section{BIBLIOGRAPHY}

Agus Raharjo, 2002, Cybercrime: Pemahaman dan Upaya Pencegahan Kejahatan Berteknologi, PT. Citra Aditya Bakti; Bandung;

Cita Yustisia Serfiani dkk, 2013, Buku Pintar Bisnis Online dan Transaksi Elektronik, Gramedia Pustaka Utama, Jakarta;

Qardhawi, Yusuf, 1997, Norma dan Etika Ekonomi Islam, Gema Insani Press, Jakarta;

Husni Syawali, Neni Sri Imaniyati, 2000. Hukum Perlindungan Konsumen, Mandar Maju, Bandung;

Nasution, 2003, Metode Research (Penelitian Ilmiah), Cet VI Bumi Aksara, Jakarta;

Nawawi, Razali HJ., 2009, Islamic Law on Commercial Transaction, CERT Publications, Kuala Lumpur;

Siswanto Sutojo, 1995, Analisa Kredit Bank Umum: Konsep dan Teknik, Pustaka Binaman Pressindo, Jakarta;

\section{Journals :}

Andi Aina Ilmih, A.Zulkarnain, IDEAL ELECTRONIC CONTRACT MODEL AS A FORM OF E-COMMERCE DISPUTES SETTLEMENT, Jurnal Pembaharuan Hukum, Volume VI No.1 January-April 2019;

Hendy Herijanto, Prinsip, Ketentuan dan Karakteristik Pembiayaan (Bank) Syariah, Jurnal ISLAMINOMIC Vol. V. No. 2, August 2016;

Mukhlis Lubis, INOVASI SISTEMIK PEMBIAYAAN PERJALANAN UMRAH MELALUI AMITRA SYARIAH FINANCING (STUDI KASUS PT. WAKAFA ZAIN ABUL HUSNA), Jurnal Islamic Circle, Vol.1. No.1, June 2020;

Roanna, Wage, Umrah Financing through Umrah Bailout Funds from the Fatwa Perspective of the National Sharia Council of the Indonesian Ulama, Jurnal Studi Islam "Alhambra", Volume 1, No. 1, February, 2020;

Trisadini Prasastinah Usanti, Restrukturisasi Pembiayaan sebagai Salah Satu Upaya Penanganan Pembiayaan Bermasalah, Jurnal Perspektif, Volume XI No.3, Edition July 2016;

\section{Regulation:}


Financial Services Authority Regulation (POJK) Number 11/POJK.03/2020 concerning National Economic Stimulus.

Law of the Republic of Indonesia Number 11 of 2008 concerning Electronic Information and Transactions. 